\title{
Chinese Construction Market for Foreign Construction Enterprises using SWOT
}

\author{
Wang En Zhi ${ }^{1}$ and Moon Sung Woo ${ }^{2}$
}

Received August 29, 2013 / Accepted January 22, 2014

\begin{abstract}
The remarkable growth of China's economy over the past several decades has obtained tremendous achievements. The construction industry play a leading role in this rapid economic expansion. And China's huge construction market gives it great economic influence around the world, it has attracting many enterprises to entry, although many enter barriers and market risks exist. However many construction enterprises have not doing well, especially foreign construction enterprises are not doing as well as we thought in the Chinese construction market. Although China's construction market has great development and become increasingly open, foreign investors and contractors now have much broader access to the Chinese construction market than before. But nonetheless, there are a wide range of practical problems that bring potential risks for them to invest in China. This paper aims to identify foreign construction enterprises' position by understanding the local market environment, and adopt he SWOT analysis identifies the foreign construction enterprises' strengths, weaknesses, opportunities, and threats in the Chinese construction market, to Proposes appropriate Strengths-Opportunities (SO), Weaknesses-Opportunities (WO), Strengths-Threats (ST) and Weaknesses-Threats (WT) strategies to make the foreign construction enterprises moving forward.
\end{abstract}

Keyword: Chinese construction market, foreign construction enterprises, SWOT

\section{INTRODUCTION}

China has experienced an economic growth rate averaging $10 \%$ per year for more than 20 years. In the meantime, Chinese construction industry also continues to rapidly growing and developing. The Gross output of the Construction Industry is RMB $11,705.97$ billions, it accounts for more than $24.75 \%$ of the GDP. And it employs 38.53 million people, more than $5 \%$ of the total labor force in 2011 from China statistic yearbook 2012 (CSYB 2012). And Gross output of the Construction
Industry has been growing at an average annual rate of nearly $20 \%$ within the last decade. The high growth rate of construction industry is attributable to extreme shortage of infrastructure and building space. With the China's construction market continues to rapidly growing and developing, many foreign construction enterprises have a great interest in the potential market. But from the historical data (See TABLE I) the foreign entrants was not many as expect, even more construction enterprises were exit the market.

TABLE I

NUMBER OF ENTERPRISES AND GROSS OUTPUT VALUE

\begin{tabular}{c|c|r|r|r|r|r|r|r}
\hline \multicolumn{2}{c|}{ Items } & 2006 & 2007 & 2008 & 2009 & 2010 & 2011 & CAGR \\
\hline \multirow{2}{*}{ Foreign Funded } & Number of Enterprises & 370 & 365 & 363 & 351 & 331 & 303 & $-3.92 \%$ \\
\cline { 2 - 9 } & Output value (Billion RMB) & 27.49 & 39.63 & 38.71 & 41.51 & 43.97 & 66.54 & $19.34 \%$ \\
\hline \multirow{2}{*}{ Total } & Number of Enterprises & 60166 & 62074 & 71095 & 70817 & 71863 & 72280 & $3.74 \%$ \\
\cline { 2 - 9 } & Output value (Billion RMB) & 4155.72 & 5104.37 & 6203.68 & 7680.77 & 9603.11 & 11705.97 & $23.01 \%$ \\
\hline
\end{tabular}

The regulation that allows foreign contractors to qualify as wholly foreign owned construction enterprises' has come into effect since Sep 2002, as one of the steps of the Chinese government to honor its World Trade Organization (WTO) commitments (Xu Tianji, 2005). The Number of foreign funded enterprises is 312 (1985), while after 16 years there are still only 303 foreign funded enterprises in 2011. Table 1 shows that the number of foreign funded enterprises has declined from over 370 in 2006 to 303 by 2011 at an average growth rate of $-3.92 \%$, while, at the same time the number of total enterprises in the Chinese construction industry increased from 6,016 to 7,228 for a $3.74 \%$ average annual growth rate. Gross Output value of foreign funded enterprises rapidly increased to RMB 66.54 billion by 2011. Although the average annual growth rate was $19.34 \%$ for the past ten years, it is still lower than the total average of $23.01 \%$. In addition, foreign enterprises and their output value respectively constitute just $0.42 \%$ and $0.57 \%$ of the total of construction industry shown in the figures blow (CSYB 2012).

\footnotetext{
${ }^{1}$ Master candidate, Department of Civil and Environmental Engineering, Pusan National University, Busan, South Korea, wez555@ hotmail.com (*Corresponding Author)

2,Professor, Department of Civil and Environmental Engineering, Pusan National University, Busan, South Korea,sngwmoon@pusan.ac.kr
} 

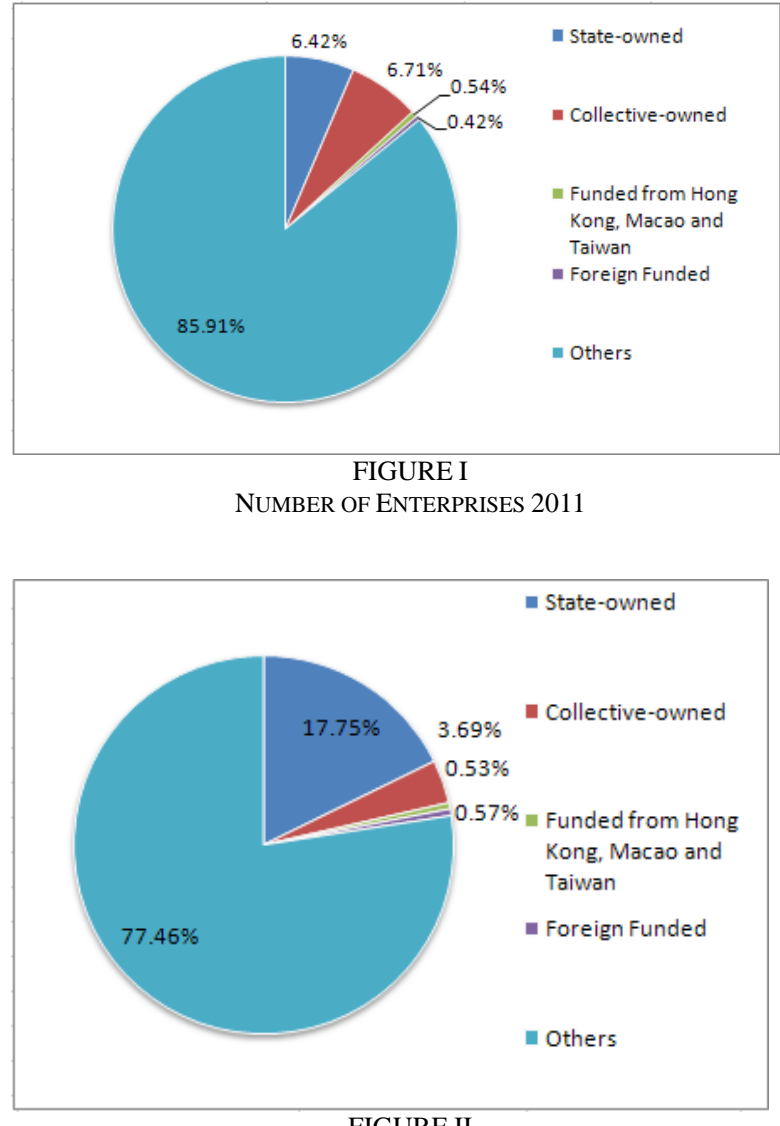

FIGURE II

GROSS OUTPUT VALUE 2011

Considered a 'high risk business', mostly because of a lack of adequate overseas environmental information and overseas construction experience, especially in the complicated China's invest environment (FFY Ling, 2009). So we hope that help foreign construction enterprises to assess their Strengths, Weaknesses, Opportunities, and Threats in the Chinese construction market by this paper. In addition, propose several strategies for them in Chinese construction market. We hold that the entrance of foreign construction enterprises will be Play an important role for Chinese construction development. The development of foreign construction enterprises won't to be threats and challenges to Chinese construction enterprises. On the contrary, it can promote healthy competition in the market. And with international competition, thus make Chinese construction enterprise more internationalization, more competitive and operation more smoothly in international construction market.

\section{RESEARCH METHODOLOGY}

At first, we do the market demand analysis of Chinese construction market, to grasp developing trends, and explore the opportunities for foreign construction enterprises by analysis relevant statistical data and industrial reports. Second, we adopt the SWOT analysis to identify Strengths, Weaknesses, Opportunities, and Threats in the Chinese construction market. And then we provide Strengths-Opportunities (SO), Weaknesses-
Opportunities (WO), Strengths-Threats (ST) and Weaknesses-Threats (WT) strategies for foreign construction enterprises.

\section{POTENTIAL MARKET}

\section{A. Energy Market}

The Company BP reported that China energy consumed around 2.61 billion tones of oil-equivalent energy, share of $21.3 \%$ global consumption, had surpassed the US as the largest energy consumer in the world in 2011. But China's energy consumption is more than its economy output 200 billion tons standard coal equivalent (SCE) average last decade (TABLE II). The coming decade China will likely see further increases to China's power output. With growth in energy demand, The Energy Industry had invested RMB 23,046 million, and the average annual growth rate reached $14.28 \%$ in last 5 years. And during The 12th Five-Year Plan from 2010 to 2015, China plans to invest RMB 11.1 trillion in the power industry, with RMB 5.3 trillion invested Hydropower and power grid are prominent items on the government's agenda. RMB 2.75 trillion will be invested in power plant construction, and RMB 2.55 trillion will be invested in power grid construction by the National Development and Reform Commission (NDRC) approved. Power generation has been an area of relatively heavy involvement by foreign players. Such expansion requires the expertise of foreign construction enterprises, as do plans to diversify away from coal-dominated power generation by means of nuclear and renewable energy sources, areas in which foreign enterprises are more experienced.

TABLE III

TOTAL ENERGY PRODUCTION AND CONSUMPTION

(Unit: Billion tons SCE)

\begin{tabular}{c|c|c|c}
\hline Year & $\begin{array}{c}\text { Total Energy } \\
\text { Production }\end{array}$ & $\begin{array}{c}\text { Total Energy } \\
\text { Consumption }\end{array}$ & $\begin{array}{c}\text { Output } \\
\text { Deficiency }\end{array}$ \\
\hline 2002 & 1506.56 & 1594.31 & 87.75 \\
\hline 2003 & 1719.06 & 1837.92 & 118.86 \\
\hline 2004 & 1966.48 & 2134.56 & 168.08 \\
\hline 2005 & 2162.19 & 2359.97 & 197.78 \\
\hline 2006 & 2321.67 & 2586.76 & 265.09 \\
\hline 2007 & 2472.79 & 2805.08 & 332.29 \\
\hline 2008 & 2605.52 & 2914.48 & 308.96 \\
\hline 2009 & 2746.19 & 3066.47 & 320.28 \\
\hline 2010 & 2969.16 & 3249.39 & 280.23 \\
\hline 2011 & 3179.87 & 3480.02 & 300.15 \\
\hline
\end{tabular}

\section{B. Sewage Treatment Market}

Owing to rapid growth in industrial activities and urbanization, about $50 \%$ of the country's wastewater is currently released into rivers and the sea without any treatment. According to the Ministry of Water Resources, We can see a rising trend from 53.68 billion tons in 2006 to 65.92 billion tons in 2011, with an annual increase of approximately 2.45 billion tons on average (FIGURE III). On the contrary, the sewage treatment is still a problem with severe under-investment and under-penetration, environmental pollution and sewage pipeline networks 
not being fully set up in many cities. China's wastewater treatment only reached 39.31 billion $\mathrm{m}^{3}$ by 2011 in sewage treatment ratio of $80 \%$. The 12 th Five-Year Plan for sewage treatment aims to improve its sewage treatment capacity. Acoording to the plan, China will invest USD 430 billion in sewage treatment. Up to March 2013, China completed a total of 3,451 municipal wastewater treatment plants more than 111 by 2012 . China's water demand growth, supply shortages and water pollution make considerable risks and opportunities for investors in China's water treatment field. And the government will provide most of the finance; some projects would be open to foreign investors.

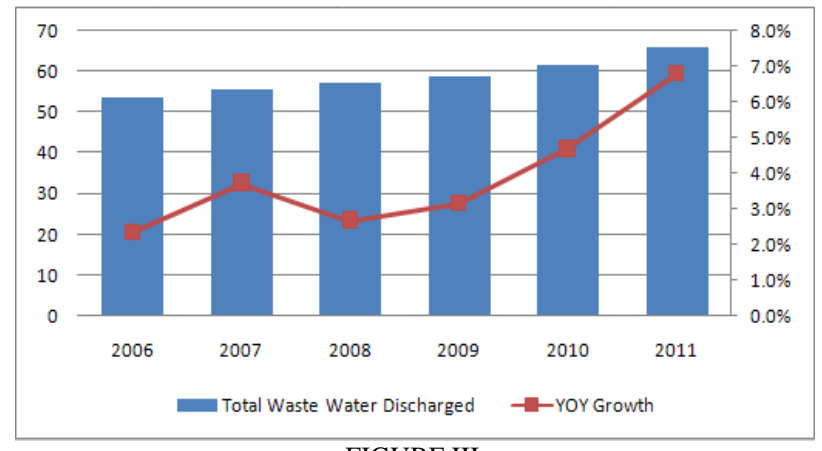

FIGURE III

TOTAL WASTE WATER DISCHARGED. (UNIT: BILLION TONS)

\section{Transportation Market}

Transportation is another promising area for foreign enterprises in China. In the 12th five years plan, China is giving high priority to its railway network. China plans investing RMB 700 billion annually in rail projects and extend high speed rail network to $16,000 \mathrm{~km}$ by 2015 , construct 7 new highways originating from Beijing, 9 new expressways running north to south, and 18 running east to west. The mileage of new highways will reach $89,000 \mathrm{~km}$. And China continues to support the development of new airport, increasing the number of airports from 175 to 230 , plans to invest more than RMB 1.5 trillion in developing china's aviation industry. China government will also focus on improvement of inner river transportation infrastructure, High-grade navigable inland waterways from $10,200 \mathrm{~km}$ to $13,000 \mathrm{~km}$ (See TABLE IV)

TABLE IV

MAIN TARGET OF TRANSPORTATION DEVELOPMENT

\begin{tabular}{l|c|c}
\hline \multicolumn{1}{c|}{ Items } & 2010 & 2015 \\
\hline High speed rail $(10000 \mathrm{~km})$ & 1.30 & 1.60 \\
\hline Highways (10000 km) & 398.40 & 450 \\
\hline Expressways (10 000 km) & 7.40 & 10.8 \\
\hline Number of deep water berth & 1774 & 2214 \\
\hline $\begin{array}{l}\text { High-grade Navigable Inland } \\
\text { Waterways (10 000 km) }\end{array}$ & 1.02 & 1.3 \\
\hline Number of Civil Airport & 175 & $\geq 230$ \\
\hline
\end{tabular}

\section{Western Region Market}

Construction expenditures in the western region are expected to register the faster gains of any region in china. It's benefited by the government's "Great Western Development" strategy, which will result in sizable increases in spending on infrastructure and manufacturing facilities in the area. According to a statement issued by the State Council, the economies of western regions will grow at paces faster than the national average. In term of different regions in 2011, the investment in eastern, central and western regions reached 704.44, 254.59, 205.61 billion RMB, respectively rose by $21.60 \%, 21.77 \%$ and $23.10 \%$ over the last year (FIGURE IV). In addition China had invested in 178 key projects constructed in total investment of RMB 3.68 trillion from 2000 to 2012. The NDRC indicated that the economies of western regions expanded by an average of 13.6 percent from 2006 to 2015, and the government will continue to focus on transportation and water conservancy projects in infrastructure construction during the 12th Five-Year Plan period, including the construction of railway, high way, airport and water allocation projects, etc. About 15,000 $\mathrm{km}$ of railways will be opened in the western regions through the end of 2015 , with $365,000 \mathrm{~km}$ of highways and $8,000 \mathrm{~km}$ of railways built during the period, according to data from the NDRC.

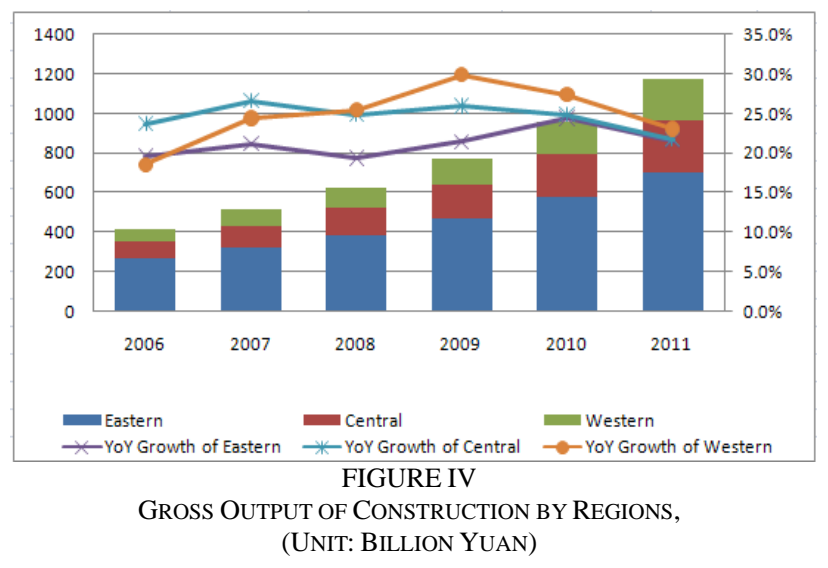

\section{E. International Construction Market}

Another opportunity for foreign construction enterprises is cooperate with Chinese construction enterprises in global market, where Chinese construction enterprises are expanding their market share. In 2012, Chinese investors made direct investment overseas in 4,425 enterprises in 141 countries and regions. Direct investment overseas amounted to USD 77.22 billion, up by $28.6 \%$ year-on-year, of which equity investments and other investments were USD 62.82 billion, accounting for $81.4 \%$, and earnings reinvested were USD 14.4 billion, accounting for $18.6 \%$ released by China International Contractors Association. The report of The Top 225 International Contractors shows that many Chinese construction enterprises have entered into the ranking (TABLE V), and have large share of African and Asian construction market. But more of them losses with 
experience shortage and mismanagement. For example, One of China's largest construction contractors, the China Railway Construction Corporation, is set to record a RMB 4.15 billion (USD 640 million) loss on the 'Mecca Light Rail Project' in Saudi Arabia. It is really an opportunities for foreign enterprises in international market, where is without lots of restrictions form china's government, and foreign construction enterprises can provide technical services, mechanical equipments, consultancy services by cooperate to realize mutual benefits.

TABLE V

MARKET SHARE OF CHINESE CONTRACTORS IN TOP 225 INTERNATIONAL CONTRACTORS

\begin{tabular}{|c|c|c|c|c|}
\hline \multirow{2}{*}{ Year } & \multirow{2}{*}{$\begin{array}{c}\text { Number of firms } \\
\text { in Raking }\end{array}$} & \multicolumn{2}{|c|}{ INT'L Revenue } & \multirow{2}{*}{$\begin{array}{c}\text { Growth Rate } \\
\%\end{array}$} \\
\hline & & \$ MIL & Share $\%$ & \\
\hline 2006 & 46 & 100.7 & 5.3 & 14.0 \\
\hline 2007 & 49 & 162.9 & 7.3 & 61.8 \\
\hline 2008 & 47 & 226.8 & 7.4 & 39.2 \\
\hline 2009 & 50 & 432.0 & 11.1 & 90.5 \\
\hline 2010 & 54 & 505.7 & 13.2 & 17.1 \\
\hline 2011 & 51 & 570.6 & 14.9 & 12.8 \\
\hline 2012 & 52 & 627.1 & 13.8 & 9.9 \\
\hline
\end{tabular}

\section{F. Green Building Market}

Driven by huge demand for space, about 2 billion $\mathrm{m}^{2}$ of new buildings are being constructed every year. According to data from the Ministry of Housing and Urban-Rural Development, The buildings account for roughly $25 \%$ of China's total energy use estimated. Under the current Five-Year Plan, China has explicitly stated that green buildings is one way of meeting the target of reducing energy consumption by $16 \%$ and carbon emissions by $17 \%$ for every unit of GDP by 2015 . Regulatory targets and incentives in the Plan aim to accelerate the green building market. The Chinese government stated that $30 \%$ of all new construction projects should be green buildings by 2020 . The green building market is developing and growing rapidly year after year, and its market holds tremendous potential.

\section{G. Disaster Protection Construction Market}

The Yearbook 2012 shows that, 432.9 million people were affected by natural disasters, caused economic losses of RMB 30.96 billion in 2011. Moreover, as a result of the Sichuan earthquake (2008) tragedy, which is China's worst natural disaster in three decades killed 69,227 people and destroyed RMB 84.51 billion worth of property and infrastructure. The natural disasters likes floods, typhoon, blizzards have made the Chinese Government more clear that stronger buildings able to withstand such events are not just advisable but necessary. To address that concern, the government has committed to making solid investments to strengthen its construction disaster protection capability. China will be efforts made to carry out various plans concerning disaster prevention and reduction, such as industrial bases, transportation trunk lines, communication center and evacuation centers. However China's disaster protection market is still at an early stage of its development. The construction technology of most construction enterprises cannot meet the demands of disaster protecting. To the construction enterprises, which have relevant advanced technology and rich construction experience, focus on the emerging market is a good choice.

\section{SWOT ANALYSIS FOR FOREIGN CONSTRUCTION ENTERPRISES}

\begin{tabular}{|c|c|}
\hline $\begin{array}{l}\quad \underline{\text { Strengths }} \\
\text { - Technological Advantage } \\
\text { - Good Service Consciousness } \\
\text { - Project Management } \\
\text {-Human Resources }\end{array}$ & $\begin{array}{l}\text { Weaknesses } \\
\text { • No Local Network } \\
\text { •High Cost } \\
\text { - Regulation }\end{array}$ \\
\hline SWC & Analysis \\
\hline $\begin{array}{l}\quad \text { Opportunities } \\
\text { •Invest Environment } \\
\text { •Huge Infrastructure Demands } \\
\text {-Internationalization of China } \\
\text { Construction }\end{array}$ & $\begin{array}{l}\text { Threats } \\
\text {-Local Protectionism } \\
\text {-Contract Risk } \\
\text {-Intense Competition }\end{array}$ \\
\hline
\end{tabular}

FIGURE V

FOREIGN CONTRACTION

ENTERPRISES SWOT ANALYSIS IN CHINA

\section{A. Strengths}

\section{1) Technological Advantage}

Although Chinese construction enterprises Constantly developing their technologies, but still fall far behind in some professional techniques, which foreign enterprises have been the front runners, such as design and construct of power stations, intelligent buildings, and tunnels etc. Moreover foreign construction enterprises have advantages of possessing construction machine and equipment (TABLE VI), which have higher efficiency and productivity. So China would have to turn to some foreign construction enterprises for technical support for some time.

TABLE VI

MACHINES CONFIGURATION ON CONSTRUCTION ENTERPRISES BY

\begin{tabular}{c|c|c}
\hline \multicolumn{3}{|c}{ REGISTRATION STATUS } \\
\hline Enterprises & $\begin{array}{c}\text { Value of Machines } \\
\text { Per Laborer } \\
\text { (Yuan/person) }\end{array}$ & $\begin{array}{c}\text { Power of Machines } \\
\text { per Laborer } \\
\text { (kw/person) }\end{array}$ \\
\hline Domestic Funded & 12004.1 & 5.7 \\
\hline $\begin{array}{c}\text { Funded from } \\
\text { Hong Kong, } \\
\text { Macao and Taiwan }\end{array}$ & 8402.2 & 4.0 \\
\hline Foreign Funded & 24401.4 & 6.7 \\
\hline
\end{tabular}

\section{2) Good Service Consciousness}

Foreign construction enterprises support Careful and thorough project service, which covers whole process of design and construction. Otherwise foreign construction enterprises pay a great attention to customer satisfaction. Mistakes are inevitable during projects but instead of argue with the client, they resolve them quickly. This attitude has helped them to maintain a good reputation. They approach serves as the cornerstone of their reputation for awardwinning, quality construction. Compared with foreign 
construction enterprises, China's domestic enterprises lack of service those attitudes. The high quality service consciousnesses make foreign firms more competitive.

\section{3) Professional Project Management}

Most of the construction projects in China don't finish on time or on budget. And valuable man-hours are wasted result in projects hard on schedule (Hubert Vaughan, 2010). Furthermore, material wastage is usually high cause of poor workmanship and careless handling of construction materials. The Chinese construction enterprises even ignore construction standard frequently. Obviously they are lack of effective management. While the foreign construction enterprises are have more experience in project management, are usually able to deliver on quality as well as other important issues such as safety, time and budget.

\section{4) Human Resources}

Since the construction services principally depends on human resources. Human resources would significantly affect the competitive advantage particularly in construction market. Therefore, foreign construction enterprises offer employees higher salary, training program, and clear career development. As a result, the enterprise has expanded its business rapidly in China and its business profit has been improving because the local talents and their advantages have contributed to the operation of the enterprises.

TABLE VII

LABOR PRODUCTIVITY ON CONSTRUCTION ENTERPRISES BY REGISTRATION STATUS

\begin{tabular}{c|c|c|c|c|c}
\hline \multirow{2}{*}{ Enterprises } & \multicolumn{5}{|c}{$\begin{array}{c}\text { RE Terms of Gross Output Value } \\
\text { (Thousand Yuan/person) }\end{array}$} \\
\cline { 2 - 6 } & 2007 & 2008 & 2009 & 2010 & 2011 \\
\hline Domestic Funded & 147.5 & 161.2 & 184.6 & 203.7 & 231.8 \\
\hline $\begin{array}{c}\text { Funded from } \\
\text { Hong Kong, } \\
\text { Macao and Taiwan }\end{array}$ & 207.8 & 224.7 & 226.7 & 192.7 & 437.3 \\
\hline Foreign Funded & 227.3 & 249.6 & 277.1 & 304.9 & 510.9 \\
\hline
\end{tabular}

\section{B. Weaknesses}

\section{1) No Local Network}

Pearce (1992) pointed out in his study on construction marketing that not only must the clients be aware of contractors and their products, but also contractors must make initiatives in building up relationships with clients. And a good understanding of local practices is extremely important. Compared to foreigner enterprises, Chinese construction enterprises are familiar with the local culture and practices, relationship. However it is more difficult for foreign construction enterprises to build up business links with local clients. This difficulty is typical in China where a strong regional characteristic have. And there is a tendency to first develop personal relationships with their business partners before getting down to the specifics of negotiation. Compared to foreign construction enterprises with domestic enterprises are in the advantageous position to make acquaintance with project clients in the market.

\section{2) High Cost}

Chinese construction enterprises' low operation costs enable them to adopt the low cost strategy and be cost competitive against foreign firms. Porter (1980)'s generic strategies for company to success is cost leadership in a competitive environment. The centre part of this strategy is to be less expensive than competitors in the whole range of a company's activities (Warszawski 1996). However, the foreign construction enterprises have higher operation cost compared to local competitors. The higher cost may be caused by expensive office overhead, high salaries of expatriates, and costly materials.

\section{3) Regulation}

In China, construction enterprises operate businesses under a complicated regulatory system. It is essential for a firm to catch up with the updated information on various regulations and policies and gain a proper understanding of these regulations in order to formulate appropriate businesses strategy. However, foreign construction firms are difficult to understanding construction standards and codes, which have changed several times during the previous decade.

\section{Opportunities}

\section{1) Invest Environment}

China has improved its investment environment and market access especially after joining the WTO in 2001. The China government has achieved great success with great effort in reforming and improving the invest environment in market (TABLE VI). It is establishing a contract guarantee system for construction works to tries to improve the credit environment in the construction market, thus helping foreign construction enterprises to minimize their losses from the contract breach or payment default by project clients. This development presents opportunities indirectly for foreign construction enterprises to develop business in the Chinese construction market.

TABLE VIII

DISTANCE TO FRONTIER OF INVEST ENVIRONMENT

\begin{tabular}{l|c|c|c|c|c|c|c}
\hline Country & 2006 & 2007 & 2008 & 2009 & 2010 & 2011 & 2012 \\
\hline Singapore & 90.2 & 90.2 & 90.4 & 90.6 & 90.9 & 91.7 & 91.7 \\
\hline U.S.A & 84.6 & 84.3 & 84.2 & 85 & 84.9 & 85.2 & 85 \\
\hline Canada & 83.3 & 83.5 & 83.5 & 83.3 & 83.5 & 84.7 & 83.8 \\
\hline $\begin{array}{l}\text { South } \\
\text { Korea }\end{array}$ & 74.5 & 75 & 76 & 76.9 & 79.8 & 80 & 81.5 \\
\hline Japan & 76.9 & 78.1 & 77.9 & 77.7 & 77.7 & 77.9 & 77.9 \\
\hline China & 46.3 & 51.9 & 53.3 & 56.7 & 58.4 & 59.3 & 59.5 \\
\hline
\end{tabular}

\section{2) Huge Infrastructure Demand}

Infrastructure construction sector remain to fastest growing. And growth will benefit by state-led efforts to raise and upgrade the country's infrastructure by continuing urbanization. Over half of the population now lives in urban areas, 681 million people out of a total 1.34 billion at the end of 2011. The United Nations forecasts that the proportion of urban dwellers will reach $75 \%$ by 2050. It will bring serious problems, like power shortages, 
Urban Water Supply \&Drainage problem, traffic problem, environmental pollution, and so on to be a serious problem that China faces with the fast development. China will be continuing demand for more and better infrastructure as new urban areas.

\section{3) Internationalization of China Construction}

With china's WTO entry, the domestic enterprises have more chances to participate in the international construction market. Meanwhile, China's local market also further is opened up to the foreign construction enterprises. However China's construction enterprises have not enough Competition to win the international market. So the domestic enterprises expected that cooperation with the international contractors to learn the advanced project management, gain experience to make them internationalization. That creates favorable opportunities between domestic construction enterprises and foreign construction enterprises to conduct mutually beneficial cooperation.

\section{Threats}

\section{1) Local Protectionism}

There are many restrictions on permits for foreign construction enterprises, such as to obtain and upgrade licenses, access bank loans, and undertake construction projects, foreign enterprises does not receive equal treatment with domestic competitors. Foreign enterprises are often allowed to perform construction projects financed by international organizations such as the World Bank, the Asian Development Bank and by foreign governments, or those projects which are wholly financed by foreign enterprises. The foreign construction enterprises difficult to get support from the Chinese government or domestic bank.

\section{2) Intense Competition}

With opening of Chinese construction market and relaxing of admittance limitation, the numbers of construction enterprises are increasing quickly. The construction industry cannot but facing the intense competition. FIGURE VI shows that all of the CR8 are blow 20\%. According to the American economist Bain on the criteria for the classification of industrial concentration, the industrial market structure is decentralized competitive (CR8<20\%), Namely redundant firms existence, china market structure is not reasonable. However, the intense competition places downward pressure on their contract prices and profit margins. The foreign construction enterprises could lose market share to their competitors and experience an overall reduction in their profits.

\section{3) Contract Risk}

The Chinese contraction enterprises generally lack of awareness about contract. Therefore they do not more care about their credibility and take their responsibilities. Thus breach of contract is a typical problem in the Chinese construction market. For example, many organizations are resisting the implementation of the new tending and biding regulations, and as a result, the continued lack of transparency in the current tendering and bidding procedures still exist. Foreign constructors also face severe partnering and bidding restrictions. They are blocked by unpublished restrictions and procedures that result in costly delays.

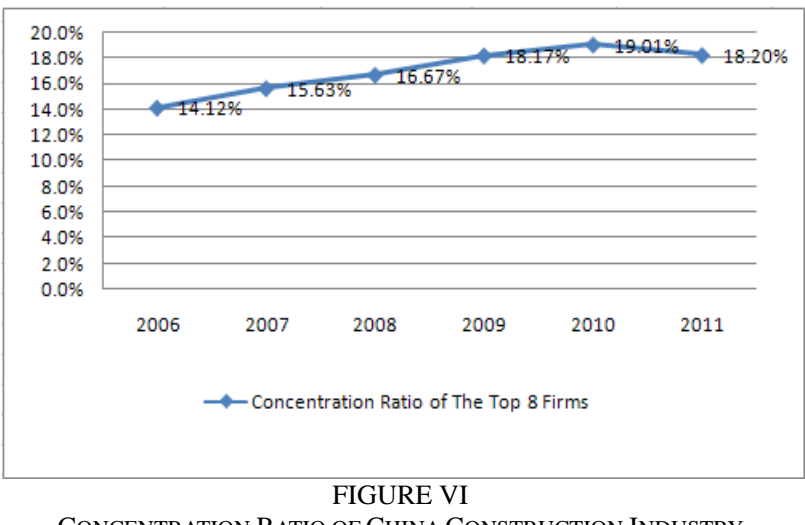

CONCENTRATION RATIO OF CHINA CONSTRUCTION INDUSTRY

\section{STRATEGIES FOR FOREIGN CONSTRUCTION ENTERPRISES}

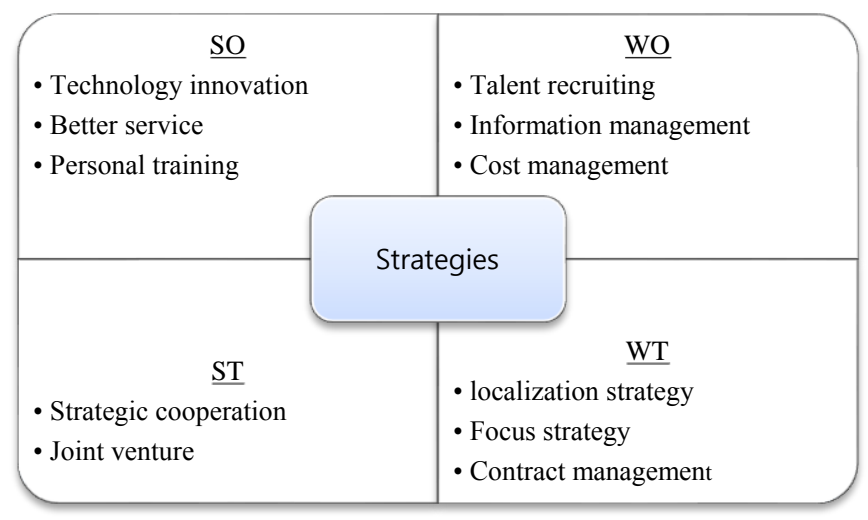

FIGURE VII

SWOT STRATEGIC ALTERNATIVES MATRIX

\section{A. SO Strategy}

\section{1) Technology Innovation}

Technological innovation of products is a motive power for enterprises' development as all known. The foreign construction enterprises should continuously focus on gain a competitive advantage through technology differentiation in market. For example, enterprises can look for new technology to meet the "green" requests of clients to ensure the successful completion of projects to control noise, reduce dust and treat sewage. By technology innovation to develop the core technology, making the foreign construction enterprises have core competence and producing core product in the market.

\section{2) Better Service}

The foreign construction enterprises should improve their competitiveness by provides high quality service. They should effort to make their products or services in low cost, effective, optimize. And continuous taking innovation in services to create their core competencies 
that cannot easily be imitated.

\section{3) Personal Training}

Foreign construction enterprises need to place a great deal of emphasis upon expertise of their workforce because this will be the source of the firm's name and reputation. So the foreign construction enterprise need more invest on personal training and skill development programs. Specific training of personnel for work is therefore likely to provide a sustainable competition advantage to the firms.

\section{B. ST Strategy}

\section{1) Strategic Cooperation}

Foreign construction enterprises should establish a good relationship with the appropriate partner, It is imperative that they succeed in china's construction market. A few factors like access to capital, political influence, and operational capability must be considered to find strategic partners. In generally, the state-owned enterprises are difficulty to approach given their size and influence. The foreign enterprises could utilize their core competencies to create synergies with the state-owned enterprises. But medium and small enterprises are more readily approachable and construct a cooperation relationship with once a firm has determined that access the potential of Chinese construction industry is essential component of its forward-looking strategy, the challenge of engagement then remains.

\section{2) Joint Venture}

Joint venture is a win-win way for both foreign and Chinese construction enterprises. Chinese construction enterprises can benefit by learning from foreign enterprises, which have superior design and technical ability and management practices. At the same time, foreign firms benefit from JVs because with a local partner, they can overcome unfamiliar with the new market, and penetrate the market directly without being encumbered by the problem of licensing (Badger and Mulligan 1995).

\section{WO Strategy}

\section{1) Talent Recruiting}

For the foreign construction enterprises, it is necessary to recruit and train adequate integrated talents who not only are good at international engineering management and tender, but also have the knowledge of laws, economy, technique and finance. They must establish rules for the management of human resource, and employ talents in relevant fields, and support a systemic career planning. Moreover, based on a clearly incentive mechanism for able to attract the talents.

\section{2) Information Management}

A project's efficiency depends on the integrated operation of many information including manpower, materials, machinery, money, management. However, Enterprises can't get the market information in time and the channel of the information sharing and exchanging is blocked inside. Therefore, Enterprises must establishment the information systems base on the internet and the intranet. They will help to improve the quality and speed of project related decision making, integrate processes, manage supply chains, sequence work flow, improve the life-cycle management of buildings and infrastructure.

\section{3) Cost Management}

Moving forward without a clear idea of goals and plans may be asking for costs to spiral out of control. So the foreign construction enterprises should establish costcontrol system to provide a means of comparing actual with budgeted expenses and thus draw attention, in a timely manner, to operations that are deviating from the project budget. And to generate data for valuing variations and changes to the contract and potential claims for additional payments (Bennett 2003). By cost management, the enterprises can identification of any work items whose actual costs are exceeding their budgeted costs, with subsequent actions to try to bring those costs into conformance with the budget.

\section{WT Strategy}

\section{1) Localization Strategy}

Localization strategy is one of the most effective measures for foreign construction enterprises success, make the enterprises enter easily and smoothly. And also bring benefits to them form some advantages such as low labor cost, local relationship, local information etc. First, enterprise can recruit most of the managers, technicians and construction teams in local the enterprise must the local. Second, Because of the culture difference between two countries, foreign construction enterprises' corporate culture should better to adapt to local culture, in language, values, beliefs, education, custom, etiquette, partiality, manners of consumption, and also human resource management. Third, the foreign enterprises should operate the enterprises complying with the rules and modes of local market, to reduce many conflicts.

\section{2) Focus strategy}

Foreign construction enterprises could focus on a few target markets by cooperation with domestic enterprises uses their intellectual property and valueadded service. As we mentioned Above, Infrastructure market, Western region market, International construction market, Green building market and Disaster protection market are that target markets. Foreign construction enterprises should be distinct groups with specialized needs. By focusing their marketing efforts on one or two narrow market segments and tailoring their marketing mix to these specialized market. They can better meet the needs of that narrow market. The Focus strategy is most suitable for relatively small firms but can be used by any enterprises. A focused strategy should target market 
segments that are less vulnerable to substitutes or where a competition is weakest to earn above-average return on investment.

\section{3) Contract management}

The Contract management is necessary to prevent the losses, because of international construction with high risk, and the foreign construction enterprises are lack of adequate information and local construction experience. Contract managers must monitor cost, scope, quality, and time frame and must ensure that all contract conditions are met. The foreign enterprises must undertake projects strictly in according to the contract to avoid contract disputes. On the other hand, the foreign construction enterprises must claim for any loss under the contract .It is significant for protecting enterprise itself benefits and promoting construction market that contractual.

\section{CONCLUSIONS}

Even if in Chinese construction market exist many enter barriers and problems, but it still attracting foreign construction enterprises by the potential from huge demand. Especially, infrastructure market, western region market, green building market, disaster protection construction market was mentioned by 12th Five-Year Plan. And the invest environment of Chinese construction market are opened gradually and the demand of internationalization Chinese construction enterprises also could to be opportunities for enter the Chinese construction market. In the complexity Chinese construction markets, the foreign construction enterprises could build strategic cooperation or joint venture with local construction enterprises, and focuses on a few target markets to make their expand the market more smoothly. Meanwhile strengthen their own advantage by technology innovation, improve service and project management, and personal training constantly make them more competitive. And through recruit and train personal, build up information management system and cost-control system for overcome the problems like local network, high cost. We hope the research in this study can provide useful references to foreign construction enterprises assess their strength, weakness, opportunity, and threat, and help them improve their operations in Chinese construction market by SO, ST, WO, WT strategies.

\section{REFERENCES}

[1] W.W. Badger, D.E. Mulligan, "Rationale and benefits associated with international alliances", Journal of construction engineering and management, vol. 121, no. 1, pp. 100-111, 1995.

[2] J.S. Bain, "Barriers to new competition: their character and consequences in manufacturing industries", AM Kelley, 1993.

[3] F.L. Bennett, "The management of construction: A project lifecycle approach", Routledge, 2003.

[4] C. Zhengxing, H. Shengyue, G. Lianwei, "Internationalization Strategies for China's Construction Enterprises", Proceedings of 2005 International Conference on Management Science and Engineering, 2005.

[5] J.R. Cui, "An Empirical Study of Regional Differences of Chinese Construction Industry", Advanced Materials Research, vol. 250, pp. 4057-4060, 2011.
[6] ENR, "The top 225 International Contractors: Engineering newsRecord", 2012.

[7] H. Vaughan, "Corporate Management and Project Management Practices", Powerpoint, Tsinghua University, Beijing, China, 2007.

[8] F.Y.Y. Ling, S.P. Low, S.Q. Wang, H.H. Lim, "Key project management practices affecting Singaporean firms' project performance in China.", International Journal of Project Management, vol. 27, no. 1, pp. 59-71, 2009.

[9] P. Pearce, "Construction marketing: A professional approach", Thomas Telford, 1992.

[10] M.E. Porter, "Competitive strategy: Techniques for analyzing industries and competitors author: Michael e. porter, publisher: Free press", 1998.

[11] L.Y. Shen, Z.Y. Zhao, D.S. Drew, "Strengths, weaknesses, opportunities, and threats for foreign-invested construction enterprises: A China study", Journal of construction engineering and management, vol. 132, no. 9, pp. 966-975, 2006.

[12] A. Warszawski, "Strategic planning in construction companies", Journal of construction engineering and management, vol. 122, no. 2, pp. 133-140, 1996.

[13] T. Xu, NJ. Smith, D.A. Bower, "Forms of collaboration and project delivery in Chinese construction markets: Probable emergence of strategic alliances and design/build", Journal of Management in Engineering, vol. 21, no. 3, pp. 100-109, 2005.

[14] C.S. Yearbook, "National Bureau of statistics of China", China Statistical Yearbook, 2002-2012.

[15] L. Yuping, "The Concentration Ratio of Chinese Construction Industry Market", Proceedings of Management and Service Science (MASS), International Conference on IEEE, pp. 1-4, 2010. 